\title{
COPD in Non-smoking Elderly Men at Sea Level and High Altitude: Comparing Anthropometric Characteristics and Physiological Responses
}

\author{
EPOC en Hombres de Edad Avanzada No Fumadores a Nivel del Mar y en Altura: \\ Comparación de las Características Antropométricas y Respuestas Fisiológicas
}

Angel Moreno* \& Omar Espinoza-Navarro**

MORENO, A. \& ESPINOZA-NAVARRO, O. COPD in non-smoking elderly men at sea level and high altitude: comparing anthropometric characteristics and physiological responses. Int. J. Morphol., 31(2):618-622, 2013.

SUMMARY: The World Health Organization considers cigarette smoke as a major risk factor and causal agent of chronic obstructive pulmonary disease (COPD); however, smoke from biomass in poorly ventilated environments may be the major causative agent in developing countries. There is little epidemiological evidence of COPD in relation to the use of biomass fuels and altitude of the place of residence, and there is no record of the morphological and physiological characteristics of patients with COPD living at different altitudes. The objective of this research was to compare a) morphological characteristics: weight, height and body mass index (BMI) and b) physiological responses: spirometric record, heart rate, oxygen saturation and hemoglobin concentration in a sample ( $\mathrm{n}=30$ ) of adults aged between 60-75 years, non smokers, exposed to smoke from biomass fuels, diagnosed with COPD, living at sea level (San Miguel de Azapa, 580 m.a.s.l, $\mathrm{n}=10$ ) and high altitude (Putre, 3500 meters, $\mathrm{n}=20$ ). The results among residents from sea level versus high altitude showed no significant differences in morpho-anthropometric variables such as weight $(70.5 \pm 6.8 / 69.7 \pm 6.1)$, height $(1.58 \pm 0.08 / 1.56 \pm$ $0.05)$ and BMI (29.1 $\pm 2.5 / 28.5 \pm 1.9)$. Similar behavior was observed in the spirometric records of FVC $(2.66 \pm 0.54 / 2.48 \pm 0.40)$ and FEV1 (1.86 $\pm 0.72 / 1.84 \pm 0.55)$. Significant differences were observed for physiological variables such as heart rate $(65 \pm 5 / 90 \pm 3)$, oxygen saturation $(93 \pm 2.7 / 79 \pm 4)$ and hemoglobin concentration $(14 \pm 2 / 19 \pm 2)$, respectively. These results manifest the greater physiological effort made by individuals from high altitude to cope both environmental and related from COPD hypoxia. We conclude that there are distinct physiological responses among patients with COPD living at high altitude and sea level.

KEY WORDS: COPD; Altitude; Anthropometry; Elderly men; Chile.

\section{INTRODUCTION}

The World Health Organization considered chronic obstructive pulmonary disease (COPD) the fourth leading cause of death and disability, anticipating that it will be the third cause during the first two decades of the XXI century (WHO, 2002). The prevalence of COPD in the general population is estimated to be about $1 \%$, rising abruptly above $10 \%$ in the population over 40 years and thus significantly increasing its prevalence as a function of age. The PLATINUM study showed that the prevalence of COPD differs according to exposure and population characteristics; in Latin American countries it ranges from $15.8 \%$ to São Paulo, $7.8 \%$ for Mexico City, $19.7 \%$ for Montevideo, $16.9 \%$ for Santiago and $12.1 \%$ for Caracas, being higher in men, people older than 60 years and smokers (Menezes et al., 2005).
COPD is defined by the Global Initiative for Chronic Obstructive Lung Disease (GOLD) as a pathological process characterized by airflow limitation, usually progressive and associated with an abnormal inflammatory response in the lungs in response to particles or gases (WHO). New evidence indicates that COPD might be a systemic inflammatory disease, affecting the metabolism and performance of skeletal and cardiac muscles (Barnes \& Celli, 2009), and which also might produce an accelerated aging of pulmonary system by the action of oxidative stress (Ito et al., 2012). Diagnostic confirmation is done by spirometry post bronchodilator when the percentage value of the FEV1/FVC ratio in the test is at least 30\% lower than expected for the patient according to sex, age and height (Anthonisen et al., 1994). The cardinal symptom and main reason for the initial consultation is

* Master on Biologial Sciences Programme, Faculty of Sciences, Universidad de Tarapacá, Arica, Chile.

**Faculty of Sciences, Department of Biology, Universidad de Tarapacá, Arica, Chile. 
dyspnea, because it interrupts the ability to carry out normal daily activities, work or exercise (Qaseem et al., 2011). Although the main risk factor reported is consumption and exposure to tobacco smoke (Forey et al., 2001), the use and exposure to biomass fuel smokes in poorly ventilated environments might be a particularly important mechanism in poor regions and determine much of the global prevalence of COPD (Buist et al., 2008). Investigation of the effect of altitude on the epidemiological pattern of COPD have shown that permanent residence in high altitude would be associated with high mortality levels and high incidence of cor pulmonale (Coté et al., 1993; Luks \& Swenson, 2007). However, in a recent review by Laniado-Laborin et al. (2012), found out that both the prevalence and severity of COPD would be lower in relation to the augment of residence altitude of patients. Studies in areas of high altitude in the South Central Andes have been conducted with an epidemiological approach and showed the impact of biomass smoke on respiratory health (Albalak et al., 1999); however, there are not reports so far that consider the effect of high altitude on the morphology and behavior of physiological variables among people with COPD.

In consideration of the evidence above, we suggest that rural Andean communities of northern Chile (2000-4500 m.a.s.l.) would be a suitable target to investigate the morphological variability of people and physiological responses associated with the clinical features of COPD related to high altitude. Thus, the objective of this research was to measure and compare (based on the altitudinal gradient in the region) morpho-anthropometric -weight, height, body mass index (BMI)- and physiological variables -heart rate (HR), oxygen saturation $\left(\mathrm{SpO}_{2}\right)$, forced vital capacity (FVC), forced expiratory volume (FEV) and hemoglobin $(\mathrm{Hb} \%)$ - in elderly men, aged $60-75$ years, nonsmokers, diagnosed with COPD, that reside at sea level (Azapa, 580 m.a.s.l.) versus high altitude residents (Putre, 3500 m.a.s.1.).

\section{MATHERIAL AND METHOD}

The study was performed in the extreme northern region of Chile, in two rural locations with high Aymara indigenous population, Azapa (580 m.a.s.l.) and Putre (3500 m.a.s.1.). Both populations have similarities in ethnic and socioeconomic structure, and in the use of biomass as fuel in poorly ventilated environments. The universe of the study $(n=60)$ was established from males aged 60-75 years under medical supervision for COPD (2010-2012) in health centers in Putre and Azapa. We determined a random sample of 30 individuals (Azapa, $n=10$; Putre, $n=20$ ), considering the following inclusion criteria: diagnosis of COPD, male, nonsmoker, aged over 60 and below 75 years old, absence of crisis in the last three months, with a history of exposure to biomass smoke. Individuals were invited to participate voluntarily in this study. The protocols and research methodology and sample collection were approved by the Committee of Ethics / Bioethics at the University of Tarapacá.

Volunteers were asked to answer a simple questionnaire to know the time of exposure to biomass smoke and working history. During the days prior to the registration of spirometry, each volunteer was trained to achieve at least three acceptable records. Then assessments were performed according to standardized procedures (Pellegrino et al., 2005) (Vitalograph spirometer, model 6800). Subsequently, morphological anthropometric variables were registered using a medical scale and following procedures previously reported by the authors (Espinoza-Navarro et al., 2009) (HealthoMeter medical scale, model WA402KL). The physiological variables were obtained using a pulse oximeter (Nonin, model Onyx ${ }^{\circledR}$ Vantage 9590). The concentration of hemoglobin (Hb CC) was obtained by a hemoglobin concentration analyzer (HemoCue, model Hb 201+) according to methods previously described by the authors (Espinoza-Navarro et al.), and following the recommendations of the manufacturers. Registration and data analysis were performed using the Epi Info -7 software (CDC, 2012). The normal distribution of the data was determined by Shapiro-Wilk test and the Student's t test was applied to determine significant differences between means $(\mathrm{p}<0.05)$.

\section{RESULTS}

Table I summarizes the general characteristics of the population under study according to residence site. The occupation is mostly rural farmers (60\% for Azapa and 55\% for Putre). Most patients showed a long history of exposure to smoke from biomass for domestic purposes ( 30-40 years) such as food preparation and house heating. The study population of Putre (3500 meters) showed higher rates of severity of symptoms of COPD.

Table II shows the morpho-anthropometric and physiological characteristics of populations residing at sea level (Azapa) versus high altitude (Putre). Height, weight and BMI showed no significant differences between populations. Spirometric records of forced vital capacity (FVC), forced expiratory volume in one second (FEV1) and the percentage differential rate (FEV1/FVC) among both 
Table I. General characteristics of volunteers from Azapa Valley (580 m.a.s.1.) and Putre (3500 m.a.s.1.). Current related symptoms: (+), infrequent, non disturbing daily activities; $(++)$, relatively frequent, occasional disturbance of daily activities; $(+++)$, very frequent, strong disturbance of daily activities. $\dagger$ masl: meters above sea level.

\begin{tabular}{lcc}
\hline Residence place (sample size) & Azapa valley (n=10) & Putre (n=20) \\
\hline Altitude of residence place ( ${ }^{\dagger}$ masl) & 580 & 3500 \\
Age (yr) & $70 \pm 3$ & $71 \pm 3$ \\
Occupation (\%) & $6(60 \%)$ & $11(55 \%)$ \\
Crop farmer & - & $5(25 \%)$ \\
Animal farmer & $2(20 \%)$ & - \\
Agriculture trader & $1(10 \%)$ & $3(15 \%)$ \\
Transportation & $1(10 \%)$ & $1(5 \%)$ \\
Others & & \\
Motives of exposure to biomass smoke & $10(100 \%)$ & $12(60 \%)$ \\
Cooking needs & - & $8(40 \%)$ \\
Domestic heating needs & $30 \pm 5$ & $40 \pm 3$ \\
Exposure time (yr) & & ++ \\
Current related symptoms & + & ++ \\
Cough & ++ & + \\
Dyspnoea & + & + \\
Headache & & + \\
\hline
\end{tabular}

Table II. Anthropometric and physiologic characteristics of volunteers from sea level location (Azapa) and high altitude location (Putre). FVC: Forced vital capacity, FEV1: Forced expiratory volume in first second; SpO2: Partial pressure of oxygen saturation, Hb: Hemoglobin concentration. $\dagger$ masl: meters above sea level.

\begin{tabular}{|c|c|c|}
\hline Reside nce place (sample size) & Azapa valley $(n=10)$ & Putre $(n=20)$ \\
\hline Altitude residence place ('masl) & 580 masl & 3.500 masl \\
\hline Age (yr) & $70 \pm 3$ & $71 \pm 3$ \\
\hline \multicolumn{3}{|l|}{ Anthropometric characteristics } \\
\hline Size $(m)$ & $1.58 \pm 0.08$ & $1.56 \pm 0.05$ \\
\hline Weight (kg) & $70.5 \pm 6.8$ & $69.7 \pm 6.1$ \\
\hline $\operatorname{BMI}\left(\mathrm{kg} / \mathrm{m}^{2}\right)$ & $29.1 \pm 2.5$ & $28.5 \pm 1.9$ \\
\hline \multicolumn{3}{|l|}{ Spirometric register } \\
\hline $\mathrm{FVC}(\mathrm{L} / \mathrm{min})$ & $2.66 \pm 0.54$ & $2.48 \pm 0.40$ \\
\hline $\mathrm{FEV}_{1}(\mathrm{~L} / \mathrm{min})$ & $1.86 \pm 0.72$ & $1.84 \pm 0.55$ \\
\hline $\mathrm{FEV}_{1} / \mathrm{FVC}(\%)$ & $0.70 \pm 0.28$ & $0.74 \pm 0.27$ \\
\hline \multicolumn{3}{|l|}{ Pulse oximetry responses } \\
\hline Cardiac frequency (bpm) & $65 \pm 5$ & $90 \pm 3^{*}$ \\
\hline $\mathrm{SpO}_{2}(\%)$ & $93 \pm 2$ & $79 \pm 4^{*}$ \\
\hline \multicolumn{3}{|l|}{ Hb concentration } \\
\hline $\mathrm{Hb}(\%)$ & $14 \pm 2$ & $19 \pm 2 *$ \\
\hline
\end{tabular}

$* \mathrm{P}<0.05$.

populations showed no significant differences. However, heart rate (HR) in high altitude residents showed a significant increase $(\mathrm{p}<0.05)$ compared to that observed at sea level $(90 \pm 3 / 65 \pm 5)$. A similar tendency was observed with hemoglobin concentration, with a significant increase (19 \pm 2$)$ in Putre inhabitants versus Azapa residents (14 \pm 2 ).

The oxygen saturation manifested a significant decrease in the population from Putre versus the population from Azapa $(79 \pm 4 / 93 \pm 2)$.

\section{DISCUSSION}

The magnitude and impact of the socioeconomic and health problem that COPD represents at worldwide level makes it necessary to posses current and relevant scientific information on the characteristics of the disease in different geographical areas and under different conditions of life ( $\mathrm{Hu}$ et al., 2010). This research specifically sought to determine differences between Andean populations living in altitude and sea level when diagnosed with COPD.

The spirometric register represents one of the best criteria for diagnostic confirmation of COPD (Pellegrino et al.). The results obtained among populations from sea level and high altitude showed no significant variability mostly because of the homogeneity in the anthropometric characteristics of these populations, which supports previous reports from other researchers who have noted that pulmonary function recorded by spirometry would be strongly influenced by gender, race and weight-height (Harik-Khan et al., 2002).

By contrast, the basic physiological responses assessed such as heart rate (HR), oxygen saturation $\left(\mathrm{SpO}_{2}\right)$ and hemoglobin concentration ( $\mathrm{Hb} \mathrm{CC}$ ) varied significantly depending on the altitudinal level of residence for people with COPD. These results demonstrated that in addition to hypoxia resulting from COPD (Kent et al., 2011), the high altitude ecosystem implies specific physiological strategies to cope with environmental hypoxia (Beall, 2000). The human model of response to high altitude hypoxia is characterized by changes in their respiratory, cardiovascular and haematopoietic physiology, combined over time to gradually restore an adequate oxygenation level. Initially, improved oxygen uptake and transportation through an increase in ventilation and cardiac output is noticed, while the distribution of oxygen is subsequently optimized through the acceleration of erythropoiesis (Smith et al., 2008).

The results obtained in this study 
demonstrate a significant increase in heart rate and hemoglobin concentration in the high altitude population versus the population from the sea level location; this would be part of the physiological responses necessary to capture, transport and distribute environmental oxygen in high altitude (Rupert \& Hochachka, 2001). The highest concentration of hemoglobin in the residents of high altitude locations would allow them to deal with the debt in environmental oxygen caused by the lower barometric pressure (Villafuerte et al., 2004). This response against hypoxia is controlled at the cellular level by the HypoxiaInducible Factor (HIF), which directly or indirectly regulates near one hundred genes that act through a great variety of functional pathways, including hematopoiesis, angiogenesis, cell growth, apoptosis, energy metabolism and vasomotor regulation (Semenza, 2009). Although the action of HIF is crucial for the regulation of the systems and respond to the hypoxic request, HIF action can also lead to maladaptive responses such as polycythemia generation in COPD patients or to the development of chronic mountain sickness for residents of such locations (Kent et al.). The model developed in this research and its results may contribute to the arguments raised by León-Velarde et al. (1994), who linked chronic low respiratory diseases and chronic mountain sickness with hypoxaemia and excessive erythrocytosis.

The altitude variable has only recently joined the general discussion of COPD and has begun to be explored as an impact factor in its epidemiology; however, it does not yet have significant population studies (LaniadoLaborin.) even though millions of people sporadically live at, work or travel to high altitude regions (Luks \& Swenson).

Finally, based on the results obtained and in the absence of a health strategy or care protocols that consider geographical variability and its effects on biological responses of individuals, we suggest the need to continue the research efforts on the altitudinal variable and its effects on health and disease conditions, in order to contribute in the development of inclusive health policies that can accommodate social and biological variability of the population from the national territory and from the entire South-Central Andean macroregion.

\section{CONCLUSIONS}

The results of morpho-anthropometric and physiological records in COPD populations from high altitude -Putre $(3500 \mathrm{~m})$ - and from a sea level location Azapa (580msnm)- led us to conclude that: Variables such as weight, height, BMI and spirometric records in both populations showed no significant differences. The basic physiological characteristics evaluated showed that heart rate (HR) of the population from high altitude is significantly higher $(\mathrm{p}<0.05)$ than the HR of the population from sea level locations. The oxygen saturation $\left(\mathrm{SpO}_{2}\right)$ in high altitude populations is significantly lower $(\mathrm{p}<0.05)$ than that observed in the population from sea level locations. The concentration of hemoglobin ( $\mathrm{Hb} \mathrm{CC}$ ) in high altitude populations is significantly higher $(\mathrm{p}<0.05)$ than the $\mathrm{CC}$ $\mathrm{Hb}$ level in populations from sea level locations.

\section{ACKNOWLEDGEMENTS}

This research was supported by Universidad de Tarapacá through Major Project UTA: 4712-13.

MORENO, A. \& ESPINOZA-NAVARRO, O. EPOC en hombres de edad avanzada no fumadores a nivel del mar y en altura: comparación de las características antropométricas y respuestas fisiológicas. Int. J. Morphol., 31(2):618-622, 2013.

RESUMEN: La Organización Mundial de la Salud señala al humo del cigarrillo como principal factor de riesgo y agente causal de la enfermedad pulmonar obstructiva crónica (EPOC), sin embargo, el humo de biomasas en ambientes mal ventilados sería el mayor agente causal en regiones en vías de desarrollo. Existe escasa evidencia epidemiológica de la EPOC en relación al uso de combustibles de biomasas y la altitud del lugar de residencia y no se dispone de antecedentes de las características morfológicas y fisiológicas de pacientes con EPOC viviendo en diferentes altitudes. El objetivo de esta investigación fue comparar a) características morfológicas: peso, talla e índice de masa corporal (IMC) y b) respuestas fisiológicas: registro espirométrico, frecuencia cardiaca, saturación parcial de oxígeno y concentración de hemoglobina, en una muestra $(n=30)$ de adultos mayores de entre 60 - 75 años, no fumadores, expuestos al humo de biomasas, diagnosticados con EPOC, residentes a nivel del mar (San Miguel de Azapa, $580 \mathrm{msnm}, \mathrm{n}=10$ ) y en altura (Putre, $3.500 \mathrm{msnm}, \mathrm{n}=20$ ). Los resultados entre residentes de nivel del mar versus altura, no muestran diferencias significativas en las variables morfo-antropométricas de peso $(70.5 \pm 6.8 / 69.7 \pm 6.1)$, talla (1.58 $\pm 0.08 / 1.56$ $\pm 0.05)$ e IMC $(29,1 \pm 2,5 / 28,5 \pm 1,9)$. Igual comportamiento se observa en los registros espirométricos de CVF $(2.66 \pm 0.54 / 2.48 \pm 0.40)$, VEF1 $(1.86 \pm 0.72 / 1.84 \pm 0.55)$. Si se observan diferencias significativas en las variables fisiológicas de frecuencia cardiaca (65 $\pm 5 / 90 \pm 3)$; saturación parcial del oxígeno $(93 \pm 2,7 / 79 \pm 4)$ y de concentración de la hemoglobina $(14 \pm 2 / 19 \pm 2)$ respectivamente. Estos resultados, expresan el mayor esfuerzo fisiológico realizan los individuos de altura para enfrentar la hipoxia ambiental y aquella derivada de la EPOC. Se concluye que existen respuestas fisiológicas diferenciadas entre pacientes con EPOC viviendo en altura y a nivel del mar.

PALABRAS CLAVE: EPOC; Altura, Antropometría; Adultos mayores; Chile. 


\section{REFERENCES}

Albalak, R.; Frisancho, A. \& Keeler, G. Domestic biomass fuel combustion and chronic bronchitis in two rural Bolivian villages. Thorax, 54(11):1004-8, 1999.

Anthonisen, N.; Connett, J.; Kiley, J.; Altose, M.; Bailey, W.; Buist, A. S.; et al. Effects of smoking intervention and the use of an inhaled anticholinergic bronchodilator on the rate of decline of FEV1: The lung health study. JAMA, 272(19):1497-505,1994.

Barnes, P. \& Celli, B. Systemic manifestations and comorbidities of COPD. Eur. Respir. J., 33(5):1165-85, 2009.

Beall, C. M. Tibetan and Andean patterns of adaptation to high-altitude hypoxia. Hum. Biol., 72(1):201-8, 2000.

Buist, A.; Vollmer, W. \& McBurnie, A. Worldwide burden of COPD in high- and low-income countries. Part I. The Burden of Obstructive Lung Disease (BOLD) Initiative. Int. J. Tuberc. Lung Dis., 12(7):703-8, 2008.

Coté, T. R.; Stroup, D. F.; Dwyer, D. M.; Horan, J. M. \& Peterson, D. E. Chronic obstructive pulmonary disease mortality: a role for altitude. Chest, 103(4):1194-7, 1993.

Espinoza-Navarro, O.; Vega, C.; Urrutia, A.; Moreno, A. \& Rodríguez, H. Anthropometric Patterns and Oxygen Consumption (VO2) of School-children Aymara and Non-Aymara of 10-12 Years, Living in High Altitude $(3500 \mathrm{~m})$ and the Plain $(500 \mathrm{~m})$, from Chile. Int. J. Morphol., 27(4):1313-8, 2009.

Forey, B. A.; Thornton, A. J. \& Lee, P. N. Systematic review with meta-analysis of the epidemiological evidence relating smoking to COPD, chronic bronchitis and emphysema. BMC Pulm. Med., 11:36, 2001.

Harik-Khan, R. I.; Fleg, J. L.; Muller, D. C. \& Wise, R. A. The effect of anthropometric and socioeconomic factors on the racial difference in lung function. Am. J. Respir. Crit. Care Med., 164(9):1647-54, 2002.

Hu, G.; Zhou, Y.; Tian, J.; Yao, W.; Li, J. \& Li, B.; et al. Risk of COPD from exposure to biomass smoke: A metha-analysis. Chest, 138(1):20-31, 2010.

Ito, K.; Colley, T. \& Mercado, N. Geroprotectors as a novel therapeutic strategy for COPD, an accelerating aging disease. Int. J. Chron. Obstruct. Pulmon. Dis., 7:641-52, 2012.

Kent, B. D.; Mitchell, P. D. \& McNicholas, W. T. Hypoxemia in patients with COPD: cause, effects, and disease progression. Int. J. Chron. Obstruct. Pulmon. Dis., 6:199-208, 2011.

Laniado-Laborin, R.; Rendón, A.; Batiz, F.; Alcantar-Schramm, J. \& Bauerle, O. High altitude and chronic obstructive pulmonary disease prevalence: a casual or causal correlation? Arch. Bronconeumol., 48(5):156-60, 2012.
León-Velarde, F.; Arregui, A.; Vargas, M.; Huicho, L. \& Acosta, R. Chronic mountain sickness and chronic lower respiratory tract disorders. Chest, 106(1):151-5, 1994.

Luks, A. M. \& Swenson, E. R. Travel to high altitude with pre-existing lung disease. Eur. Respir. J., 29(4):770-92, 2007.

Menezes, A. M.; Perez-Padilla, R.; Jardim, J. R.; Muiño, A.; Lopez, M. V.; Valdivia, G.; et al. Chronic obstructive pulmonary disease in five Latin American cities (the PLATINO study): a prevalence study. Lancet, 366(9500):1875-81, 2005.

Pellegrino, R.; Viegi, G.; Brusasco, V.; Crapo, R.; Burgos F.; Casaburi, R.; et al. Interpretative strategies for lung function tests. Eur. Respir. J., 26(5):948-68, 2005.

Qaseem, A.; Wilt, T.; Weinberger, S.; Hanania, N.; Criner, G.; van der Molten, T.; et al. Diagnosis and management of stable chronic obstructive pulmonary disease: a clinical practice guideline update from the American College of Physicians, American College of Chest Physicians, American Thoracic Society, and European Respiratory Society. Ann. Intern. Med., 155(3):179-91, 2011.

Rupert, J. \& Hochachka, P. Genetic approaches to understanding human adaptation to altitude in the Andes. J. Exp. Biol., 204(Pt. 18):3151-60, 2001.

Semenza, G. L. Regulation of oxygen homeostasis by hypoxiainducible factor 1. Physiology (Bethesda), 24:97-106, 2009.

Smith, T. G.; Robbins, P. A. \& Radcliffe, P. J. The human side of hypoxia-inducible factor. Br. J. Haematol., 141(3):325-34, 2008.

Villafuerte, F. C.; Cárdenas, R. \& Monge-C, C. Optimal hemoglobin concentration and high altitude: a theoretical approach for Andean men at rest. J. Appl. Physiol., 96(5):1581-8, 2004.

WHO. World Health Report, 2002. Available in: http://www.who.int/ whr/2002/

\section{Correspondence to:}

Prof. Dr. Omar Espinoza Navarro

Faculty of Sciences, Department of Biology

Universidad de Tarapacá

Avenida General Velásquez No 1775, Arica

CHILE

Email: oespinoz@uta.cl

Received: 04-04-2013

Accepted: 05-05-2013 